\title{
The Effect of Using KWL (Know-Want-Learned) Strategy on Reading Comprehension Of 5th Grade EFL Students in Kuwait
}

\author{
Amel AlAdwani ${ }^{1}$, Anam AlFadley ${ }^{2}$, Maha AlGasab ${ }^{1} \&$ Ahmad F. Alnwaiem ${ }^{2}$ \\ ${ }^{1}$ English Department, College of Basic Education, Public Authority for Applied Education and Training \\ (PAAET), Kuwait \\ ${ }^{2}$ Curriculum \& Instruction Department, College of Basic Education, Public Authority for Applied Education and \\ Training (PAAET), Kuwait \\ Correspondence: Amel AlAdwani, English Department, College of Basic Education, Public Authority for \\ Applied Education and Training (PAAET), Kuwait.
}

Received: November 26, 2021

Accepted: December 8, 2021

Online Published: December 23, 2021

doi: $10.5539 /$ elt.v15n1p79

URL: https://doi.org/10.5539/elt.v15n1p79

\begin{abstract}
Metacognitive reading strategies play an essential role in improving reading comprehension. This study explores the effects of English metacognitive reading strategies and reading comprehension in Kuwaiti primary school students as foreign language learners; this experimental study tries to find a relationship between students' metacognitive strategies, metacognitive strategies, and students' reading performance. Participants were fifth grade EFL students in Kuwait primary education government public schools. The students' reading comprehension was evaluated. Comprehension tracking strategies were measured using Metacognitive strategies (K-W-L Plus). While the experimental groups (B) received instructions according to (K-W-L Plus) techniques, the control (A) group was trained with the traditional teaching approach based on the Kuwait national curriculum school textbooks. A questionnaire investigating the use of English and perceived English proficiency was also conducted. The results revealed that Perceived proficiency in English was not determined by the early or late pre-school age of second language acquisition. Also, bilingual students with perceived proficiency in English had better meta-cognitive reading skills than low perceived proficiency in English. Comprehension monitoring and (K-W-L) strategy was adequate and the most important predictor of reading comprehension among all students in the research sample.
\end{abstract}

Keywords: reading, EFL learners, Kuwait, public school, metacognitive awareness, KWL strategy, reading comprehension, second language acquisition

\section{Introduction}

Reading is an essential educational construct, and it is not surprising that it is difficult to define. It is a flexible skill rather than a body of knowledge (Rajabi, 2015; Sainsbury, Harriosn, \& Watts, 2006). In addition, reading comprehension is a vital issue in learning English as a foreign language. Reading Comprehension is one of the most fundamental skills a child needs to develop and nurture at home and school because it is fundamental to success in academic life and beyond (Meniado, 2016). Therefore, for students to understand a text adequately, especially in a foreign language, they will need a print awareness that can be obtained from multiple channels to facilitate word recognition (Boulware-Gooden et al., 2007). In addition to decoding skills, students need vocabulary that tracks their understanding and reflects on their reading.

Teaching reading strategies to students is not a standard practice in Kuwaiti language classrooms, meaning that public school English teachers hardly ever provide explicit instruction to language learners in using comprehension strategies while reading. Therefore, classroom practice does not always prepare students to use skills and strategies to predict, infer, analyze, accept, criticize, and evaluate by interacting with the given text. It is often promoted as an excellent way to improve students' second language proficiency (Al-Humoud \& Schmitt, 2009). Many researchers have argued that those who learn English as a foreign language have difficulty understanding English texts because they encounter foreign words and may contain unusual concepts and cultural illusions (Tagliebar, Johnson, \& Yarbrough, 1988). The inability of students to guess the meaning of new words can cause serious comprehension problems. In order to help students in the EFL class be more efficient in reading Comprehension, research evidence supports the instruction of metacognitive strategies for learners in either native language reading texts or in EFL classes (Boulware-Gooden, 2007; Khun \& Manderson, 2007; Carlisle \& Rice, 2002). 
English education in Kuwait Public schools begins in the first grade and continues through the twelve grades when students are 17 or 18 . The Ministry of Education (MOE) in Kuwait has implemented many methods and adopted different curriculums to improve English in four language skills, especially reading and writing to engage young students with printed text and actively participate in the target English language. However, Kuwaiti researchers say, "Kuwaiti English learners struggle with printed materials. Students in Kuwait's public schools are not exposed to reading materials until they reach third grade; however, English is practiced and taught from the first grade. Moreover, with this much emphasis on listening and speaking, it is inevitable that the other two skills, reading, and writing, will be neglected." (Al Darwish \& Akbar, 2013:203)

The current study introduces KWL-Plus as a new metacognitive reading strategy to Kuwait Government primary schools. Through an open questionnaire distributed to 50 English teachers teaching in primary schools, the researchers discovered that none were familiar with the KWL-Plus strategy. Accordingly, the researcher realized that EFL teachers in Kuwait had to get acquainted with new reading strategies that contribute to better reading comprehension in English Education.

\subsection{Research Problem}

Education must promote the economic well-being of the country. Reading is one of the crucial indicators of a student's educational ability (Aghaei et al., 2012). According to Brown \& Heekyeong (2015), proficient readers find their way, taking charge of their learning and using various strategies effectively, whereas others do not use strategies effectively even though they are taught how to do so. The National Institute of Child Health and Human Development, NICHD stated in the National Reading Panel (2000) that reading comprehension is critical for developing children's reading skills and, therefore, their ability to receive an education. Fairbairn and Fairbairn (2001: 2) state, "better readers, make more successful students." Many students, especially those who study English and get high scores in school, can quickly enter higher education, receive scholarships abroad, find promising jobs, and build a global network for themselves and their communities (Wijaya \& Puti, 2015). Indeed, reading is part of the debate, and there is an urgent need for a new type of test to show how well they have developed sufficient reading competence to serve students' personal and social needs.

In Kuwait, due to the current calls and growing debate of members of the Kuwait National parliament, researchers, educators, and parents for a radical Educational improvement and National Education reforms, especially from the alarming educational reports from UNESCO or as Kuwait social media put it, "John Blaire Report about Kuwait education" who presented an academic Education Report dated October 2009 stating that the education laws in Kuwait are at risk because the achievement tests are lower than other countries at the same economic and financial level. (Alqabas newspaper, October 13, 2019). Another call is from scholars such as the head of the Department of English at Kuwait University, "the overall education outcomes in English are poor" (Alqabas Newspaper, 2019). Recently, a government report (April, 2021) highlighted that a high school graduate level is equivalent to the seventh intermediate academic level. Despite the high-spending on-school students, the government acknowledged that the education gap reached 5 years in its program (Aljareeda newspaper, 2021).

\subsection{Research Questions}

According to the above, specific areas of assessment in this study are:

1) What are the proficiency levels of fifth-grade students in the Kuwait EFI class regarding reading comprehension?

2) Is the cognitive tracking technique KWL-Plus a reliable determinant of the level of reading comprehension among fifth year EFL students in Kuwait public schools?

3) Are there any differences in reading Comprehension according to demographic variables; gender, teacher nationality?

These questions were examined in two sample groups (experimental and control) of fifth grade EFL students in two public schools from two different education regions.

This study examines the effect of the meta-cognitive strategy KWL-PLUS on improving the reading comprehension of Fifth Grade Kuwait EFL students. It aims to improve fifth-grade students' ability to create meaning from text.

\subsection{Significance of the Study}

To the researcher's knowledge, the only study on the school sample on reading instructions in Kuwait was conducted by Alshaye (2002), who evaluated the effectiveness of metacognitive strategies on Arabic lessons on reading comprehension and comprehension strategies of the eleventh-grade students in Kuwait. In secondary school, he studied the Arabic language with male students, 120 students from four male groups from two educational districts in Kuwait, two groups in which he used the traditional reading method, and the other two groups adopted the strategy, metacognitive strategy groups. He found that the two groups with the metacognitive and the strategy group had a significantly higher and positive effect on understanding than traditional strategy 
groups. Looking at reading as an educator in higher education for over 20 years, we have become more aware that students who do not progress in reading and writing find it more challenging to put together the parts than to learn separately. Clay (1979), for example, found that the poorest readers tended to do exactly and only what they were taught and seemed to be instructional; as a result, although they knew the letter-sound equivalents, they did not use efficiently; they only used them.

This study is critical because 1) As far as the researchers know, this is the first study to use reading comprehension and KWL-plus on the young EFL student Sample. 2) we need to fulfill valid and accessible research findings on young EFI students for all students and policymakers that show how large-scale reading proficiency levels responded to the Kuwait education report, particularly in the first phase, 3) we need it because reading comprehension is arguably the most critical outcome and indicator of future reform movements designed to improve both teaching and assessment (Pearson \& Ham, 2006). Finally, 4) We need such a study to answer the many calls for dedicated teachers who are desperate for valuable tools to help their everyday learners meet their individual needs.

Understanding the need for accessible, flexible assessments is key to identifying steps to improve reading skills. The search for flexibility can also reveal the need for large-scale assessments that do not rely on just one way for students to demonstrate competency. As the Kuwaiti academic researcher notes: "Teachers in Kuwait, similar to teachers in many other EFL countries, teach the test and are seen by students and parents as figures of information providers and authorities" (Alnouh, 2008, p. 239).

\section{Review of the Literature}

Reading ability is both essential and crucial to a child's academic success. Slavin, Madden, Karweit, Dolan, and Wasik (1994) stated that students who have completed third grade do not have reading skills are unlikely to graduate from high school. Grade-level skills are essential foundations for any accessible assessment. Readers should access words in texts, use the structure of texts, make sense of words because they are embedded in a text, understand sentences and paragraphs, and understand what they are reading.

American National Assessment Governing Board assessments NEAP. expect students' understanding of the text to be influenced by their ability to apply critical components of reading: phonemic awareness, phonetics, fluency, and vocabulary (National Assessment Governing Board, 2009). Also they focuses on "cognitive goals" at the classroom level and the mental processes or types of thinking that underlie "reading comprehension"; Cognitive goals serve to guide the test development process in which item writers 'target' the types of thinking when writing these processes or items" (National Assessment Governing Board, 2009 NAEP Reading Framework, p. 39).

Reading Comprehension is the click of an invisible understanding consisting of mental changes that cannot be directly observed (i.e., we cannot see it), but we can use indicators to measure it. This is an elusive structure because the processes that readers' minds use when interacting with texts are invisible - it is undoubtedly multifaceted and complex and, therefore, difficult to capture (Sainsbury, Harrison, \& Watts, 2006). Understanding is the click of understanding, "as mentioned by some reader experts: the process of text comprehension has always provoked a bored but still enthusiastic research within the research community. reading or "understanding" is, by its very nature, a phenomenon that can only be evaluated, studied or observed indirectly." (Pearson and Johnson, 1978; Johnston, 1984).

Therefore, in this study, the term Reading Comprehension is "an intentional, active, interactive process that occurs before, during and after a person reads a particular piece of writing" (Brummitt-yale, 2008, p. 2). In the current study, we will adopt Sainsbury et al. diagram of the reading process:

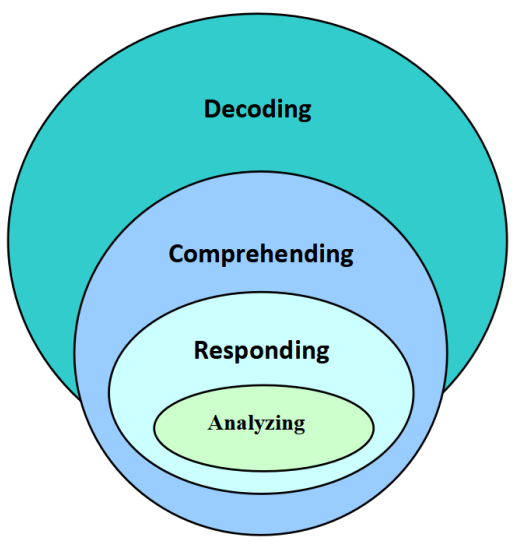

Figure 1. Diagram of the Construct of reading 
The reading diagram is highly effective since it depicts a schematic structure for the reading process. In addition, it reflects the critical stage of qualifications and curriculum standards for reading tests in England and Wales, QCA, 2004; ACCAC, 2004, and the tests used in the PIRLS and PISA international surveys are examples of this approach in figure 1 diagram (Campbell, 2001).

Meanwhile, Comprehension is accepted as an indicator of the student's reading skill (Foorman, 2003). The National Institute of Child Health and Human Development (NICHD) and U.S. Department of Education declared in 2000, a national report stated that reading comprehension is critical for developing children's reading skills and, therefore, their education (National Reading Panel, 2000). A NICHD (2000) studied 80 English learners at U.S. Schools in Metro Nashville, Tennessee, analyzes the relationship's degree to determine whether there is a predictable relationship between success in reading skills and the development of language skills. (1) the degree of correlation between reading composite scores in a nationally normed achievement test of intermediate English learners, the TerraNova Assessment Series, and students' combined language scores from the TerraNova Assessment Series, if any; (2) the degree of difference, if any, between the combined language scores of intermediate English learners from the TerraNova Assessment Series and the first language groups of students; (3) the degree of correlation, if any, between the reading composite scores of intermediate English learners in the TerraNova Assessment Series and the students' composite language scores in the Macular Assessment Program, a written and normalized achievement test for English learners; and (4) the degree of correlation, if any, between the language composite scores of intermediate English learners in the TerraNova Assessment Series and the students' language composite scores in the Macular Assessment Program. The study showed a high positive relationship between reading skill levels and language skill levels among language learners in Nashville primary school. The study provided educators with an approach to second language teaching that uses reading instruction to teach academic English.

Klingner et al. (1999) have argued that if children are to be better learners, teachers should make them aware of the psychological process that learning entails. Children can be helped and talked about their learning (Fisher, 2002). It has been assumed that helping students understand the process helps them become more conscious about handling tasks in the future (Wilaims, 2000, Gunderson, D'Silva, \& Odo, 2019). Whether the text is on a printed page, a computer screen, a T.V. commercial, or a street sign, understanding requires more than the ability to decode words. Many studies have shown that it is the teacher's responsibility to emphasize how reading in content areas helps students develop comprehension skills, such as making connections based on previous knowledge. For example, Foorman, Francis, Fletcher, Schatschneider, \& Mehta (1998) showed that practical classroom training alone could reduce reading failure to about 6 percent. Other studies show that a combination of effective classroom instruction and targeted small-group instruction can reduce the proportion of students $(\mathrm{IQ}=72-122)$ performing below the 30th percentile in early reading skills to below 2 percent (Denton \& Mathes, 2003; Foorman, 2003; Torgesen, 2002, 2004).

In Elley (1991) study that consists of four studies comparing language development of children who learned a second language in traditional classrooms and those who participated in a reading-based program in New Zealand, he found that superior performance by participants in the reading-based program in the three tests administered to examine its effectiveness.

Each time a student understands a text and reads it, he passes a ladder that leads to academic success. Thus, reading Comprehension helps students discover, explain, understand, and interpret the information contained in a text. Reading involves active, dynamic thinking and thoughtful interpretation of texts by competent readers. Research evidence has demonstrated the effectiveness of teaching strategies to activate prior knowledge as a tool to support students' reading comprehension. As a whole, the research base provides good evidence to support previous knowledge activation strategies. Prior knowledge activation is considered a research-validated approach to improving children's memory and text comprehension (Pressley \& Johnson, 1989).

Furthermore, McWhorten (1998) stated three levels of Comprehension when reading a text. It includes only facts and details, learning and memorization, and superficial understanding. Common questions used in this type of thinking are who, what, when, and where. The second is interpretative, implied, or meant more than stated. It involves drawing inferences, using previous knowledge/experience, adding new learning to old knowledge, making logical interpretations, educated guesses, and reading between the lines to determine what is meant by the phrase. The types of tests in this category are subjective and the types of questions asked are open-ended, thought-provoking questions such as why. Third, it is applied, taking what is said (literally) and then what is meant by what is said (interpreter), and then extending (apply) the concepts or ideas beyond the situation. It includes analyzing, synthesizing and applying.

\subsection{Reading Instructions in Kuwait EFL Curriculum}

The researchers examine reading Comprehension among fifth-grade students and how effectively the KWL-plus method improves comprehension skills among fifth-grade students. The education system in Kuwait consists of 
three stages: Primary stage 5 years, elementary stage 4 years, and secondary stage 3 years (Al-edwani, 2005; Al-mazeedi, 2009).

English has been introduced to the primary stage from first grade since Sept. 1993 (Al-Darwish, 2006). English is taught as a foreign language subject for 45 minutes daily, five days a week. The curriculum, including the textbooks, materials, assessment, and teacher training programs, is planned by the Ministry of Education (Alshaya, 2002). All centers or institutions for reading education or public libraries are controlled and supervised by either the Ministry of Information or the Ministry of Education; therefore, the reading instruction policy in Kuwait is centralized (Huachuca, 1992).

The Kuwait public school curriculum only uses English during the English class period. However, Arabic is the language of instruction for other school subject areas. The English curriculum in Kuwait uses the "Competency-Based Approach." According to this method, the teacher is a facilitator in the learning process; since the method is designed as a student-center approach, the teacher is directing, organizing, monitoring, helping, guiding (Richards \& Rogers, 2014). According to the ministry regulations and policies, the authentic Kuwaiti school culture, the teacher role is more teacher-centered (Alhaji, 2004). The teacher has to follow the Ministry's national curricula and finish within the allocated time for each unit in the school textbook; each unit is followed by a formal assessment for the students four-five times per term.

The overall goals of primary education in Kuwait are to equip the child with a multidisciplinary foundation to increase their potential in their future lives. Looking at the National Document for the first phase (2007), the objectives of the English instructions for the primary phase are:

"To develop the students' cognitive, affective and psychomotor needs through the four language skills in order to develop the students 'linguistic competence toward pursuing his/ her future education." (2007: 1)

The MOE documents, Followed the proficiency goals for the stage in the four skill areas, but due to the study scope on the Reading skill, the MOE objectives for the reading skill, the students will be able to:

- $\quad$ Read aloud correctly in pronunciation, stress, intonation, and punctuation.

- $\quad$ Develop the skill of silent reading, etc.

- Identify the meanings of some words through contextualization.

- $\quad$ Identify words and simple sentences.

- $\quad$ Read, understand, repeat and act out texts by native speakers (National Curriculum Document, 2005 cited in Al-Nouh, 2008).

\subsection{EFL Fifth Grade Learners in Kuwait}

Currently, Kuwait follows the National Competencies Curriculum. Each elementary school student in a public school has a continuous cumulative portfolio of learning outcomes for each class, psychological, educational, and learning outcomes, based on their Primary education curriculum competencies. Each portfolio must include an index of recorded history, printed documents of students' learning progress in all subject areas without grades. Every subject teacher at all levels must record the student's portfolio. The current problem is that once the student reaches the fifth grade, the primary student portfolio must take a combined final exam for all subject areas before they graduate and move on to the intermediate stage. Many students and their parents saw the written final exam for fifth graders as an unfamiliar major obstacle for their children, as students have not taken the final written exams for the past four years. Students were evaluated in the "Student Portfolio" with one word: Pass. or Intransitive for the last four years.

With its grading system and levels in all subject areas, this shift in the fifth grade put students, teachers, and parents under pressure. As a researcher in Kuwait, teaching at one of the higher institutes in Kuwait, Primary Education College, PAAET for more than 20 years and specializing in the English teacher's preparation program in Kuwait, we have argued that the educational environment in Kuwait is the focus towards test scores and performance ratio rather than the learning process. Teachers and students were under pressure to score high on tests and were not successfully involved in their reading success in reading experts' articles that we teach to test, not to learn (Fisher, 2002; Balchowicz et al., 2011).

Based on the background studies, the researchers in the current study investigated Comprehension reading among young EFL learners of English in Kuwaiti fifth-grade government schools by using the KWL strategy on EFL students' reading comprehension achievement. The researchers also wanted to determine whether there was a significant difference in reading comprehension achievement between the students taught using KWL-plus strategy and those who were not. The researcher adopted reading passages from the Government school's fifth grade English curriculum reading textbooks and assessed their decoding, Comprehension, and analysis ability in English as the target language. 


\subsection{Definitions of the Term}

\subsubsection{Comprehension Monitoring}

It is the process of periodically checking Comprehension during reading. It is an important aspect of meta-cognition Kolić-Vehovec, \& Bajšanski (2007). Other researchers identified the meta-cognitive as the mental process that permits planning, choosing strategies, assessing, and evaluating whether understanding a text occurred (Brown \& Palinscar, 1982). Wagoner (1983) defined it as 'an executive function, essential for competent reading, which directs the reader's cognitive processing as he/she strives to make sense of incoming information (p. 328). Indeed, Metacognition is the consciousness of your cognitive process. In other words, an awareness of what's going on in your mind while you are doing something. (Fisher, 2002)

\subsubsection{The Implementation of KWL-Plus as Related to Reading Comprehension in this Study}

KWL strategy is a teaching and learning strategy developed by $($ Ogle, 1986) and used mainly for information text. KWL stands for "what I know", "what I want to know", and "what I learned". It is of diverse aims. It contributes to readers to elicit some prior knowledge on the topic in the focused text and define a purpose on reading, monitor and evaluate their own Comprehension of the text, and develop ideas going beyond the text.

Ogle (1986), KWL-Plus reading strategy aim is helping learners to have access to crucial background information before reading nonfiction. Such KWL strategy, which is defined as accessing what I know, shaping what I want to figure out, remembering what I learned, makes a combination of a host of approaches. Embedded in its first two steps in KWL, students and the teacher are engaged in oral discussion. They reflect on their knowledge related to a topic, brainstorm a set of lists of ideas on the discussing topic, and then identify the classification of information. Next, the main contribution of the teacher is to highlight the gaps and inconsistencies existing in students' knowledge, and students develop some individual lists on things that they are to learn on the topic or questions that they tend to answer on the topic. In the last step in the KWL strategy, students read some new materials and share what they learned earlier. The KWL Plus strategy is considered as one of the meta-cognitive strategies aiming to provide students with a richer comprehension of reading texts.

Pressley (2000) argues that proficient readers can use much more appropriate comprehension techniques. Duke, Ward, \& Pearson, P. D. (2021) and Tracey and Morrow (2002) emphasize that Comprehension is a skill that improves other language arts modules, including decoding meaning, spelling acquisition, and vocabulary development.

As Ogle (1987) presents, KWL-Plus, strategy is viewed as one reading meta-cognitive strategies prompting the reader to think more deeply and critically while she or he is interacting with the reading text. As for the evaluation for the effectiveness of the KWL-Plus strategy on such a study sample, teachers can compare the learners' scores on skill sheets or comprehension questions or reading tests before and after the implementation of such an intervention. This strategy gets children to read silently with Comprehension. In addition, children relate new information to what they already know when they confirm or disconfirm the information in the $K$ column. Further, the children learn to set their own purposes for reading when they generate questions for the $W$ column. Their reading to answer these questions helps them concentrate while they are reading as they more actively monitor their own Comprehension.

The L column allows students to summarize, and due to Kuwait government school EFL context and the young EFL age 10-11 years old, the researchers asked them questions to write a mini composition passage on what they comprehend of what they read. While putting such information in their own language contributes to them finding out what they are aware of and what they are not. In turn, this is contributive to moving them into a likely next step, which consists of having them make more questions and use a wide range of resources to learn more information. Eventually, taking such a strategy into a publication step provides them with some opportunities to organize such information and write it to present it to others. This reinforces their learning on the information, involving them in doing what so-called good readers do, and teaches them on their own reading processes.

\section{Method}

This study is a quasi-experimental one that is often used in classrooms when control and experimental groups are such naturally assembled groups as intact classes, which may be similar (Lismayanti, 2014). The research design is called the nonequivalent-group pretest-posttest design (Amree \& Al Natoor, 2006) because two experimental and control groups were involved in this study.

\subsection{Instrument}

KWL-Plus was used for the purpose of this study. It is a comprehension strategy that helps students think about the text they read while they are reading. Often categorized as a study strategy, it helps students "understand" a text when they first read it by teaching them how to read and think like an effective reader. In reported that students' learning outcomes using KWL-Plus could be more satisfactory because the method could make 
students active readers and focus directly on the essence of the implicit and explicit content of the content subject in the text.

KWL-Plus is a strategy primarily used to analyze texts or documents by understanding the text and creating a mental framework for the facts that can be applied. This method was first introduced in 1941 by Francis P. Robinson of Ohio University, USA. Students' results using KWL-Plus can be expected to be more satisfactory because the KWL-Plus method can activate students. Readers and focused directly on the core or content of the implicit and explicit topic in the text (Bakhtiar, 2018).

\subsection{Procedures}

Several steps were used to use and facilitate the usage of these methods for the study:

1) There existed two tests, pretest, and posttest, given to the sample of such a study; the test means examination or trial of something to find its value, quality, and composition.

2) I have chosen the topic from the fifth grade Kuwait National Curriculum EFL textbook.

3) I Asked students to share what they know or think about the proposed textbook 1 topic. Then I record their responses (right or wrong) in the first column: K- What We Know.

4) I Recorded students' questions as this information is shared in the middle column: W- What We Want to Know.

5) Ask students to read the lesson from the student's textbook and look for information that answers their questions or expands their understanding of the topic.

6) When students have completed their reading, I focused their attention on the third Colum: L- What We Have Learned. Ask students to share new information they discovered through the reading.

7) I transformed the learner's information into a concept map and a summary (mini composition) of the selection.

8) Finally, I presented a post-reading comprehension test for the learners.

\subsection{Sample}

Participants were 140 people, from which 72 male students and 70 female students in the fifth grade were selected from two schools in two education districts, The Capitol education district (Al-Asmah) and A Suburban Education district (Mubark-Alkabeer). Fifth-grade students range in age from 10 to 11. Participants had been studying English at a public school for the last four years. (See Table 1)

Table 1. Sample Socio-demographic Background

\begin{tabular}{llll}
\hline VARIABLE & TYPE & FREQUENCIES & \% \\
\hline Gender & Boys & 72 & 51.4 \\
& Girls & 68 & 48.9 \\
Group & Control & 70 & 50 \\
\multirow{2}{*}{ Teacher's Gender } & Experimental & 70 & 50 \\
\multirow{2}{*}{ Teacher's Nationality } & Male & 38 & 27.1 \\
& Female & 102 & 72.9 \\
& Kuwait & 54 & 36.6 \\
& Non-Kuwaiti & 88 & 61.1
\end{tabular}

Table 2. Descriptive Statistics and Reliability Coefficients of Reading Comprehension Scales $(n=140)$

\begin{tabular}{llll}
\hline Scale & Mean & SD & Alpha \\
\hline Reading Comprehension Scales & 13.5 & 2.9 & .90
\end{tabular}

D. Data collection: the researchers used to read comprehension text from the Kuwait National Fifth grade Curriculum. There were two tests, pretest, and posttest, given to the sample of this study. The test means examining or trialing something to find its quality, value, and composition. It also measures an individual group's knowledge, intelligence, and ability (Hatch \& Farhady, 1982:44). The data for this study were analyzed using the SPSS. Descriptive statistics were computed to provide information on all variables and on the background of the sample in this study (see Tables $2 \& 3$ ). 


\section{Results}

The study intends to answer the following research questions:

1) What are the students' proficiency levels in reading comprehension in the Kuwait EFL classroom in the fifth grade?

2) Is the comprehension monitoring technique KWL-Plus being a reliable predictor of EFL learner reading comprehension in Kuwait government fifth-grader EFL learners?

3) Are there any differences in reading comprehension concerning the demographic variables: gender and teacher nationalities?

\section{Answering question 1:}

What are the students' proficiency levels in reading comprehension in the Kuwaiti EFL classroom in the fifth grade? (Pre-test groups).

The findings from the first question reported that both controlled and experimental groups showed a moderate level of reading comprehension. At the same time, it showed no significant mean differences between the two groups

Table 3 present the students' level of reading comprehension. The two groups showed almost similar means. The mean for the control group was (13.1), while the mean for the experimental group was (13.8). Such means have had no significant statistical differences.

\section{Answering question 2:}

Is the comprehension monitoring technique KWL-Plus being a reliable predictor of reading comprehension level among fifth-grader EFL learners in Kuwait government schools?

The study reported that the mean level for the post-test in the experimental group was higher (M. 16.02) than the control group (M. 13.8) with a significant level at (P.000), such result predicts that using KWL (Know, Want, Learned) strategy could increase the students' reading comprehension score. (See Table 3)

Table 3. Reading Comprehension Scales $(\mathrm{N}=140)$. For Control and Experimental Groups

\begin{tabular}{llllll}
\hline & \multicolumn{2}{l}{ Control Group (N=70) } & \multicolumn{4}{c}{ Experimental Group (N=70) } \\
\hline Scale & Mean & $S D$ & Mean & $S D$ & $t$ \\
Pre-Test Comprehension Scale & 13.1 & 1.9 & 13.8 & 3.2 & 1.8 \\
Post-Test Comprehension Scale & 13.8 & 3.5 & 16.02 & 2.6 & $-4.3 * *$ \\
\hline$* \mathrm{p}<.000$ & & & &
\end{tabular}

\section{Answering question 3:}

Are there any differences in reading comprehension in relation to the demographic variables: gender and teacher nationalities?

Table 4 shows a significant mean difference between the two groups based on gender. The mean score for males in the experimental group was (13.5) compared with the mean score for females (14.07) with a significant level at $(\mathrm{p}=000)$.

Gender was found to impact the student's reading comprehension level significantly. As reported in table 4, in the pre-test stage, the means for females was (14.7) while the mean for males (13.5) was found not to be statistically significant $(\mathrm{p}=.031)$. In addition, there were no significant mean differences between the two-control group based on their gender in the pre-test. Three showed the means for both males (16.1) and females (15.9) with no significant statistical differences $(\mathrm{p}=.72)$. This means that gender has significant differences in the experimental group's reading comprehension level.

The study tried to see if teachers' nationalities impact teaching reading comprehension. Results indicated that teachers' nationalities had no significant impact on students' level of reading comprehension. As seen in the table 5 in the pre-test stage, students whose' their teacher was Kuwaiti showed means of (15.9), while those students whose teachers were non-Kuwaiti teachers showed higher means of reading comprehension (16.1). Still, such means differences have no statistically differences $(\mathrm{P}=715)$.

Thus, teachers' nationality has no significant impact on students' reading comprehension. 
Table 4. Reading Comprehension Scales $(\mathrm{N}=140)$. For Control andExperimental Groups based on Students Gender

\begin{tabular}{lllllllll}
\hline & Pre-test Scale & & \multicolumn{5}{c}{ Post-Test Scale } \\
& Males (N=39) & Females (N=31) & $\mathrm{t}$ & $\mathrm{Sig}$ & Males (N=39) & Females (N=31) & $\mathrm{t}$ & $\mathrm{Sig}$ \\
\hline Scale & Mean $(S D)$ & Mean $(S D)$ & $t$ & & Mean (S.D.) & Mean (S.D.) & $t$ & \\
Experimental Group & $12.3(2.0)$ & $14(1.3)$ & .6 & .47 & $13.5(2.2)$ & $14.07(3.8)$ & .71 & .000 \\
Control Group & $14.4(3.9)$ & $13.5(3.1)$ & 1.8 & -.31 & $16.1(3.2)$ & $15.9(1.9)$ & 3.8 & .72 \\
\hline
\end{tabular}

Table 5. Reading Comprehension Scales $(\mathrm{N}=140)$. For Control and Experimental Groups based on Teacher Gender \& teachers nationalities

\begin{tabular}{lllllllll}
\hline & $\begin{array}{l}\text { Pre-test Scale } \\
\text { Kuwaiti } \\
\text { teachers }\end{array}$ & $\begin{array}{l}\text { Non-Kuwaiti } \\
\text { teachers }\end{array}$ & $\mathrm{t}$ & $\mathrm{Sig}$ & $\begin{array}{l}\text { Post-Test Scale } \\
\text { Kuwaiti } \\
\text { teachers }\end{array}$ & $\begin{array}{l}\text { Non-Kuwaiti } \\
\text { teachers }\end{array}$ & $\mathrm{t}$ & Sig \\
\hline Scale & Mean (S.D.) & Mean (S.D.) & $t$ & & Mean (S.D.) & Mean (S.D.) & $t$ & \\
Control Group & $13.6(1.1)$ & $12.9(1.08)$ & 1.3 & .082 & $12.9(1.1)$ & $14.1(3.6)$ & -1.3 & .039 \\
Experimental Group & $13.5(3.1)$ & $14.4(3.9)$ & -1.02 & .3 .03 & $15.9(1.9)$ & $16.1(3.2)$ & -.36 & .715 \\
\hline
\end{tabular}

\section{Discussion}

As Dagget and Hasselbring (2007) stated, reading should be seen as the leading learning provider for academic competence. Reading Comprehension is "a deliberate, active, interactive process that takes place before, while, and after reading a particular piece of writing" (Brummitt-yale, 2008, p. 2). In this study, it was found that the KWL-plus application method can increase the reading comprehension of Kuwaiti students. The study showed that students started by reading the main topic, title, headings, and chapter summary, improving Comprehension among young EFL students in Kuwait.

Our findings are consistent with previous studies (Amree \& Alnatoor, 20006; Ismail \& Tawalbeh, 2015), stating that using effective strategies such as the KWL-plus can improve reading performance. The findings of the second question support the findings carried out by other researchers, as KWL-Plus is practical and improves the reading skills of the experimental group (Erawati, 2012; Hamdan, 2014; Fengjuan, 2010; Casey, 2009; Al Shaye, 2002); as cited in Al-Khateeb (2010) reported that KWL is an effective reading strategy to improve students' reading comprehension.

Riswanto et al. (2014) previously reported that a group of students learning to read with the KWL strategy they saw performed better than the group learning to read traditionally. To some extent, using the KWL strategy in teaching and learning reading can also increase the classroom atmosphere through active discussion between the teacher and students or between the students themselves.

The results showed that students 'gender might be related to students' success in reading comprehension. Female students in this study scored better than the boy group. This finding supports the finding of Reilly, Neumann, and Andrews (2018), who found that female students in their research scored better than male students. Furthermore, he signed a contract with other study findings of Elui (2015) and Reilly, Neumann, \& Andrews (2019). who did not find a gender difference in student reading scores. According to Kuwaiti government law in female segregation schools, female can concentrate more on subject content than male students and, in the first instance, female can be more compatible with the pressures of their peers.

Finally, teacher nationalities do not significantly impact students' reading comprehension level; all teachers teach foreign languages and use the same strategies and instructions in reading skills regardless of their cultural background (Rajabi, 2010; Aghaei et al., 2015; Ahmed \& Rajab, 2015). In addition, the experimental groups were strictly followed by the KWL-plus method. Foreign language schoolteachers are committed to fulfilling their reading duties and following their national curriculum responsibilities, with all the profession's challenges of meeting the government's requirements for their annual recruitment in the public schools' sector.

\section{Conclusion}

During this experimental study, the researchers addressed the ability to track Comprehension among fifth graders at Kuwait public schools using the KWL-plus strategy. The results showed this. The KWL-plus technique was a valuable and effective strategy for improving the reading experience of young EFL students in Kuwait. The application of KWL-Plus can enhance students' reading experience to be more interactive with the text through collective brainstorming. It also encouraged young students to become so-called more autonomous (Aghaei et al., 2020) in reading and made teachers easier in the teaching process. The KWL-Plus strategy allows learners to 
keep new information in their long-term memory; They leave some questions unanswered, forcing students to read more.

One limitation of this study is that school teachers are not familiar with the KWL-plus strategy. The time allocated to implement the experimental groups prevented the strategy from carrying out the school teachers' compressed programs. The time factor was crucial to implementing the strategy because there were deadlines for teachers and students to complete each reading task.

\section{References}

Aghaei, K., Danyali, A., \& Rajabi, M. (2020). Critical Discourse Analysis on English Language Textbooks for Learners with Special Needs: Laclau \& Muffe Approach. Language Related Research, 11(1), 329-358. Retrieved from https://lrr.modares.ac.ir/article-14-30361-en.html

Aghaei, K., Koo, Y. L., \& Noor, N. M. (2012). Sustainable Language and Literacy Learning: A Critical Trace in English Language Education. English Language Teaching, 5(6), 54-59. https://doi.org/10.5539/elt.v5n6p54

Aghaei, K., Koo, Y. L., Noor, N. M., \& Rajabi, M. (2014). From theory to practice: Theater reading (T.R.) as a critical and transformative literacy practice in an educational development course. Procedia - Social and Behavioral Science, 118, 37-41. https://doi.org/10.1016/j.sbspro.2014.02.005

Aghaei, K., Lie, K. Y., \& Noor, N. M. (2015). Manifestation of cultural identity (S) in an Iranian English Language literacy classroom: A critical discourse analysis. e-Bangi, 12(3).

Ahmed, R. A. I., \& Rajab, H. (2015). Enhancing elementary level EFL students' reading comprehension and writing skills through extensive reading enrichment program. International Journal of English Language Education, 3(2), 28-43. https://doi.org/10.5296/ijele.v3i2.7742

Al-Barakat, Abdullah A. (1996). Identifying and Evaluating Concepts and Values in English Language Curriculum in Jordan. Ph.D. Dissertation, Um durman Islamic University.

Al-Darwish, S. (2006). An investigation of teachers' perceptions of the English language curriculum in Kuwaiti elementary schools. University of Denver.

Al-Darwish, S., \& Akbar, R. (2013). EFL Reading Motivations: Evidence from Kuwait.

Al-edwani, A. (2005). Factors contributing to student's language learning difficulties in the college of Basic Education in Kuwait. Unpublished PhD thesis, University of Newcastle upon Tyne. UK.

Alhaji, B. (2004). Investigating the primary English language classrooms in Kuwait: focusing on teacher-pupil interaction. Unpublished $\mathrm{PhD}$ thesis, University of Liverpool, UK.

Al-Homoud, F., \& Schmitt, N. (2009). Extensive reading in a challenging environment: A comparison of extensive and intensive reading approaches in Saudi Arabia. Language Teaching Research, 13(4), 383-401. https://doi.org/10.1177/1362168809341508

Aljarida news. (April, 2021). Retrieved from https://www.aljarida.com/articles/1617730537637245300

Al-Khateeb, O. S. M., \& Idrees, M. W. K. (2010). The impact of using KWL strategy on grade ten female students' reading comprehension of religious concepts in Ma'an city. European Journal of Social Sciences, 12(3), 471-489.

Almazeedi, H. (2009). An investigation of the perceptions of parents, teachers and principals concerning parental involvement in kindergartens and primary schools in Kuwait. Unpublished PhD. These, University of Newcastle, U.K.

Al-Nouh, N. (2008). Are Kuwaiti primary EFl teachers implementing a CLT- based learner centered method in their classrooms? Unpublished PhD. Theses, University of Newcastle, U.K.

Alqabas newspaper. (2019). Retrieved from https://www.alqabas.com/article/665309

Alrasheed, Hana. (2014). Examining the effectiveness of Pre-reading strategies on Saudi EFL college students' reading comprehension. English language Teaching, 7(11), 79-92. https://doi.org/10.5539/elt.v7n11p79

Al-Shaye, S. S. (2002). The effectiveness of metacognitive strategies on reading Comprehension and Comprehension strategies of eleventh grade students in Kuwaiti high schools. Ohio University.

Amree, M., \& Al Natoor, M. (2006). The impact of previous knowledge activation on the reading comprehension of a sample of under achieving students in Amman. Educational Science Studies, 3(1), 484-487.

Ayari, S. (1998). Using oral summarization to assess English reading comprehension of Arabic-speaking learners of English. Unpublished PhD thesis, University of Minnesota. 
Bakhtiar, A. (2018). Improving Students' Reading Comprehension by Using SQ3R Method. Scope: Journal of English Language Teaching, 2(2), 99-104. https://doi.org/10.30998/scope.v2i02.2405

Balchowicz, C. L. Z., Fisher, P., Ogle, D., \& Watts-Tafee, S. (2011). Vocabulary: questions form the classroom. Reading Research Quarterly, 41(4), 524-539. https://doi.org/10.1598/RRQ.41.4.5

Birch, B. M. (2002). English language reading: Getting to the bottom. Mahwan, NJ: Lawrence Erlbaum Association.

Black, P., \& Wiliam, D. (1998). Inside the Black Box: Raising Standards through Classroom Assessment. London: Department of Education and Professional Studies, Kings College.

Boulware-Gooden, R., Carreker, S., Thornhill, A., \& Joshi, M. (2007). Instruction of Metacognitive strategies enhance reading comprehension and vocabulary achievement of third- grade students. The Reading Teacher, 61(1), 70-77. https://doi.org/10.1598/RT.61.1.7

Brown, A. L., \& Palincsar, A. S. (1982). Inducing strategic learning from texts by means of informed, self-control training. Center for the Study of Reading Technical Report; no. 262.

Brown, D., \& Heekyeong, L. (2015). Teaching by Principles: An Interactive Approach to Language Pedagogy (4th ed.). New Jersy: Prentice Hall Regents.

Brummitt- Yale, J. (2008). Strategies to help engage reluctant readers in reading. Comprehension lessons plans. Retrieved from https://www.k12reader.com/strategies-to-help-engage-reluctant-readers-in-reading/

Campbell, R. (2001). Read-Alouds with Young Children. Order Department, International Reading Association, 800 Barksdale Road, PO Box 8139, Newark, DE 19714-8139.

Carlisle, J. F., \& Rice, M. S. (2002). Improving reading comprehension: Research-based principles and practice. Timonium, MD: York Press.

Casey, B. L. (2009). Using KWL strategies in reading for students with autism.

Clay, M. M. (1979). Reading: The Patterning of Complex Behavior. London: Heinemann Educational Books.

Daggett, W. R., \& Hasselbring, T. S. (2007). What we know about adolescent reading. International Center for Leadership in Education, 1-11.

Denton, C. A., \& Mathes, P. G. (2003). Intervention for struggling readers: Possibilities and challenges. In B. Foorman (Ed.), Preventing and remediating reading difficulties. Baltimore: York Press.

Dominik, W. J. (2009). Satire-(DM) Hooley Roman Satire. Pp. xii+ 189. Malden, MA and Oxford: Blackwell Publishing, 2007. Paper, £17.99, US165). ISBN: 978-1-4051-0689-4 (978-1-4051-0688-7 hbk). The Classical Review, 59(1), 132-134. https://doi.org/10.1017/S0009840X08002187

Duke, N. K., Ward, A. E., \& Pearson, P. D. (2021). The Science of Reading Comprehension Instruction. The Reading Teacher, 74(6), 663-672. https://doi.org/10.1002/trtr.1993

Elley, W. B. (1991). Acquiring literacy in a second language: The effect of book-based programs. Language learning, 41(3), 375-411. https://doi.org/10.1111/j.1467-1770.1991.tb00611.x

Elui, E. P. (2015). Effect of extensive reading approach on pupils' attitude and achievement in reading comprehension. Unpublished doctoral dissertation], University of Nigeria, Nsukka.

Erawati, N. L. P. E. P. (2012). A cpmpartive effect of metacognitive self- monitoring strategies on students' reading competency based on text types. Jurnal Pendidikan dan Pembelajaran Bahasa Indonesia, 1(1).

Fairbairn, G. J., \& Fairbairn, S. A. (2001). Reading at University: A Guide for Students. Buckingham: Open University Press.

Fengjuan. (2010). The Integration of the Know-Want-Learn (KWL) Strategy into English Language Teaching for Non-English Majors. Chinese Journal of Applied Linguistics (Bimonthly), 33(4), 77-86. https://doi.org/10.25273/etj.v2i1.723

Fisher, R. (2002). Shared thinking: metacognitive modelling in the literacy hour. Reading, 36(2), 63-67. https://doi.org/10.1111/1467-9345.00188

Foorman, B. R. (2003). Preventing and remediating reading difficulties. Baltimore: York Press.

Foorman, B. R., Chen, D. T., Carlson, C., Moats, L., Francis, D. J., \& Fletcher, J. M. (2003). The necessity of the alphabetic principle to phonemic awareness instruction. Reading and Writing, 16, 289-324. https://doi.org/10.1023/A:1023671702188

Foorman, B. R., Francis, D. J., Fletcher, J. M., Schatschneider, C., \& Mehta, P. (1998). The role of instruction in learning to read. Journal of Educational Psychology, 90, 37-55. https://doi.org/10.1037/0022-0663.90.1.37 
Gunderson, L., D'Silva, R. A., \& Odo, D. M. (2019). ESL (ELL) literacy instruction: A guidebook to theory and practice. Routledge. https://doi.org/10.4324/9780429458583

Hamdan, M. H. (2014). KWL-Plus effectiveness on improving reading comprehension of tenth graders of Jordanian male students. Theory and Practice in Language Studies, 4(11), 2278. https://doi.org/10.4304/tpls.4.11.2278-2288

Hatch, E., \& Farhady, H. (1982). Research Design and Statistics for Applied Linguistics. Newbury House Publishers. INC., Rowley.

Ismail, N. M., \& Tawalbeh, T. E. I. (2015). Effectiveness of a Metacognitive Reading Strategies Program for Improving Low Achieving EFL Readers. International Education Studies, 8(1), 71-87. https://doi.org/10.5539/ies.v8n1p71

Johnston, P. H. (1984). Assessment in reading. In P. D. Pearson, R. Barr, M. L. Kamil \& P. Mosenthal (Eds.), Handbook of reading research (pp. 147-182). New York: Longman.

Khun, S., \& Manderson, L. (2007). Community and school-based health education for dengue control in rural Cambodia: a process evaluation. Plos neglected tropical diseases, 1(3), e143. https://doi.org/10.1371/journal.pntd.0000143

King, R., \& Torgesen, J. K. (2003). Improving the effectiveness of reading instruction in one elementary school. Technical Report No. 3. Tallahassee, FL: Florida Center for Reading Research. Retrieved from https://www.fcrr.org/science/technicalreports.htm

Klingner, J. K., Vaughn, S., Tejero Hughes, M., \& Arguelles, M. E. (1999). Sustaining research-based practices in reading: A 3-year follow-up. Remedial and special education, 20(5), 263-287. https://doi.org/10.1177/074193259902000502

Kolić-Vehovec, S., \& Bajšanski, I. (2007). Comprehension monitoring and reading comprehension in bilingual students. Journal of Research in Reading, 30(2), 198-211. https://doi.org/10.1111/j.1467-9817.2006.00319.x

Kuwait Ministry of Education MOE. (2007). Retrieved from: https://www.moe.edu.kw/teacher/Documents/\%D8n/Introduction\%20to\%20implementation.pdf

Larsen-Freeman, D. (2000). Grammar: Rules and Reasons Working Together. ESL Magazine, 3(1), 10-12.

Larsen-Freeman, D. (2000). Techniques and Principles in Language Teaching. Oxford University.

Lismayanti, D. (2014). The effect of using KWL (Know, Want, Learned) strategy on EFL students' reading comprehension achievement. International Journal of Humanities and Social Science, 4(7), 225-233.

McMillen, M. (2009). The impact of academic vocabulary instruction on reading performance of sophomore students on the Florida Comprehensive Assessment Test from 2008 and 2009. University of Central Florida.

McWhorter, J. H. (1998). Identifying the creole prototype: Vindicating a typological class. Language, 788-818. https://doi.org/10.2307/417003

Meniado, J. (2016). Metacognitive reading strategies, motivation, and reading comprehension performance of Saudi EFL students. English language teaching, 9(3), 117-129. https://doi.org/10.5539/elt.v9n3p117

Mienke Droop, Ludo Verhoeven, \& Peter F. de Jong. (2017). Developmental Relations Between Reading Comprehension and Reading Strategies. Scientific Studies of Reading, 21(3), 194-209. https://doi.org/10.1080/10888438.2017.1278763

Mullis, I. V. S., Kennedy, A. M., Martin, M. O., \& Sainsbury, M. (2006). PIRLS 2006 Assessment framework and specification (2nd ed.). TIMSS \& PIRLS International Study Center Lynch School of Education, Boston College Chestnut Hill, MA: Boston College.

National Assessment Governing Board. (2007). Reading framework for the 2009 national assessment of educational progress. U.S. Department of Education: Washington DC.

National Institute of Child Health and Human Development, NIH, DHHS. (2000). Report of the National Reading Panel: Teaching Children to Read: Reports of the Subgroups (00-4754).

National Reading Panel. (2000). Teaching children to read: An evidence-based assessment of the scientific research literature on reading and its implications for instruction. Reports of the subgroups. Washington, DC: National Institute of Child Health and Human Development.

Ogle, D. M. (1986). KWL: A teaching model that develops active reading of expository text. Reading Teacher, 39, 564-570. https://doi.org/10.1598/RT.39.6.11

Parker, L. L. (2002). Achievement in reading and language development among English language learners: A comparative study. Tennessee State University. 
Pearson, P. D., \& Johnson, D. D. (1978). Teaching Reading Comprehension. The English Journal, 68(3), 88-89. https://doi.org/10.2307/814947

Pressley, M., \& Johnson, C. J. (1989). Strategies that improve children's memory and Comprehension of text. The elementary School Journal, 90(1), 3-32. https://doi.org/10.1086/461599

Rajab, H., \& Al-Sadi, A. (2015). An empirical study of reading habits and interests of Saudi university EFL learners. International Journal of Linguistics, 7(2), 1-17. https://doi.org/10.5296/ijl.v7i2.7034

Rajabi, M. (2015). Literacy practices of an English language teacher in two pre-university high-stakes examination-oriented settings (Doctoral dissertation, University of Malaya).

Rajabi, M., Lie, K. Y., \& Noor, N. M. (2010). Culture: A Wanted or Inevitable Dress in English as a Lingua Franca (ELF)? In Frontiers of Language and Teaching: Proceedings of the 2010 International Online Language Conference (IOLC 2010) (p. 305). Universal-Publishers.

Reading, E. C. (2000). A Professional Development Guide. Washington: Learning First Alliance.

Reilly, D., Neumann, D. L., \& Andrews, G. (2019). Gender differences in reading and writing achievement: Evidence from the National Assessment of Educational Progress (NAEP). American Psychologist, 74(4), 445. https://doi.org/10.1037/amp0000356

Richards, J. C., \& Rodgers, T. S. (2014). Approaches and methods in language teaching. Cambridge university press.

Riswanto, Risnwati, \& Lismayanti, D. (2014). The Effect of Using KWL (Know, Want, Learned) Strategy on EFL Students' Reading Comprehension Achievement. International Journal of Humanities and Social science, 4(7), 225-233.

Sainsbury, M., \& Campbell, J. (2003). Developing the PIRLS reading assessment. In Martin, M. O., Mullis, I. V. S., \& Kennedy, A. M. (Eds.), PIRLS 2001 technical report (pp. 13-27). Chestnut Hill, MA: Boston College.

Sainsbury, M., Harrison, \& Watts, A. (2006). Assessing reading from theories to classrooms. National Foundation for Educational Research. U.K.

Slavin, R. E., Madden, N. A., Karweit, N. L., Dolan, L. J., \& Wasik, B. A. (1994). Success for all: A comprehensive approach to prevention and early intervention.

Syah, M. (2009). Psikologi Pendidikan Dengan Pendekatan Baru. Bandung: Remaja Rosda Karya.

Taglieber, L. K., Johnson, L. L., \& Yarbrough, D. B. (1988). Effects of preceding activities on EFL reading by Brazilian college students. TESOL quarterly, 22(3), 455-472. https://doi.org/10.2307/3587289

The National Document Committee. (2007). English language objectives for the primary stage in Kuwait. Ministry of Education.

Torgesen, J. K. (2002). The prevention of reading difficulties. Journal of School Psychology, 40(1), 7-26. https://doi.org/10.1016/S0022-4405(01)00092-9

Torgesen, J. K. (2004). Lessons learned from research on interventions for students who have difficulty learning to read. In P. McCardle \& V. Chhabra (Eds.), The voice of evidence in reading research. Baltimore: Brookes.

Tracey, D. H., \& Morrow, L. M. (2002). Preparing young learners for successful reading comprehension. Comprehension instruction: Research-based best practices, 319-333.

Wagoner, S. A. (1983). Comprehension monitoring: What it is and what we know about it. Reading Research Quarterly, 28, 328-346. https://doi.org/10.1016/0273-2297(86)90002-X

Wijaya, H., \& Puti, H. P. (2015). Using KWLA Strategy to improve reading comprehension skills of Hortatory exposition texts.

Williams, M. (2000). The part that metacognition can play in raising standards in English at key stage 2. Reading, 34(1), 3-8. https://doi.org/10.1111/1467-9345.00127

\section{Copyrights}

Copyright for this article is retained by the author(s), with first publication rights granted to the journal.

This is an open-access article distributed under the terms and conditions of the Creative Commons Attribution license (http://creativecommons.org/licenses/by/4.0/). 